\title{
Competitions of Ethnographic Authenticity of Gendered Identities in Egypt
}

\begin{abstract}
Hania Sholkamy*
The notion of cross-cultural conversations rests upon... (an) assumption of the fixity and finality of the interlocutors in this conversation which, even at the hands of serious philosophical authors, tends to cause reason to degenerate to trite statements on common maxims of etiquette (Al-Azmeh 2009, 17).
\end{abstract}

Competitive claims to authenticity have plagued Egyptian discussions of gender for decades (Hatem 2011, Mostafa 2018). Feminism, the western import, the straight jacket that shapes its territory, the set of blinkers that blind the wearer to social realities or to historical processes has been questioned by advocates and enemies of gender justice. The tension between equality agendas and authenticity is not new. Scholars and activists who have reflected on this tension note the fallacy of rendering tradition as a-historical and therefore permanent or real (Khater and Nelson 1988, Al-Ali 2000). Despite which, the 'suspicions' of gender equality as a tool of cultural and political hegemony persist ${ }^{l}$ as does the debate on authenticity and whose version of equality counts. Gender rights narratives in academic, policy and research circles have been scrutinized for their irrelevance to broader publics (Abu-Lughod 2010) or dependence on structures of power (Abu-Lughod and El Mahdi 2011). El-Mahdi had this to say about these groups:

And in terms of tactics, these NGOs are focused on lobbying and appealing to those in power, as opposed to trying to build a grassroots constituency around their demands and creating pressure from below. Hence, as in most Arab countries, women's rights became associated with the dictators; the general populace in Egypt refers to marriage and divorce laws as "Susan" and "Gehan" laws, in reference to the wives of the last two Egyptian preside. (Abu-Lughod and El Mahdi 2011, 685)

Abu-Lughod has scrutinized the work of gender rights in Egypt and in Palestine by illustrating that:

\footnotetext{
* American University in Cairo, Egypt.

Cairo Studies in English (2018): https://cse.journals.ekb.eg/
} 
[T]he women's rights industry creates careers, channels funds, inspires commitments, gives credibility to new actors, creates and disrupts social networks, and legitimizes intellectual and political frameworks and ideals. Women's rights provide a conduit for foreign intervention and government involvement in ordering the daily lives of both the middle classes and those at the margins. Object of struggle among religious institutions and organizations, women's rights are also the subject of corporate sponsorship and adopted as a symbol of modernity. (Abu-Lughod 2010, 33)

The tensions of global ideals and their local practice (or abandonment) are the apt setting for this paper which discusses the implicit binaries that course through critical analysis of the story of gender work in Egypt. These dualities of ordinary and not so ordinary people, of power and people, of global and local, of indigenous and imported, and of gender or sexuality are the linchpins of otherwise fluid arrangements. In her critique of the gender rights narrative, AbuLughod proposed an ethnographic analysis of gender rights work that will shed light on how "[O]rdinary women and girls live their lives at the intersection of national media and local institutions" (Abu-Lughod 2010, 1). This recommendation is clearly an entreaty to activists and ethnographers to honour the obligation to and bias for the 'common woman'. But it is also a call that needs definition. ${ }^{2}$ For example, what is the definition of ordinary and does ordinary not change? Do these ordinary people exist at a fenced intersection that is isolated from broader contexts? Is there an intersection where ordinary girls and women live alone without extraordinary others or ordinary men and boys? Answering these questions would help those engaged in gender work respond or take up this invitation.

This paper considers the idea of ethnography as a tool that amplifies a native voice and so enables a 'real' understanding of an idea of gender. The notion that real justice is an ethnographically knowable construct that is located in a bounded cultural setting is questioned as is the possibility of 'fixing' the native voice that is legible only when in a natural environment. The paper reflects on the intersections of ordinary and unusual, of state and society, of global agendas and their vernacular renditions, to question why many seek to preclude the political life of gender at the centre/state level and privilege the social life of rights as practiced in local contexts. Ethnography can trace how the centre works at the periphery and theorize on the basis of grounded research the dynamics and directions of these articulations but it needs to be an ethnography that neither fixes the native nor creates boundaries that signal an essential difference based 
on location, class, and sex. In other words, ethnography, this paper argues, can undo the impositions of the gender straight-jacket and enable a nuanced understanding of gender dynamics and experiences if it is not bounded by its own impositions of what is culture, who is a native and where to find ordinary people!

The paper looks at examples of recent work on perceptions of the masculine and the feminine in present-day urban Egypt to argue against these partial and fragmented accounts of how people discuss gender and how rights are practiced and perceived. It uses edited transcripts from group conversations to question both formal policies for gender equality and scholarly commentary on gender. The analysis argues for social and ethnographic engagement informed by the agglomeration of identities held by men and women. The paper proposes resistance to the essentialist notion of the 'real native' whether held by progressive or autocratic interlocutors and proposes situational interpretations that enable multiple readings and possibilities.

\section{Recent Research on Masculinity and Gender}

A small team of researchers from the Social Research Centre at the American University in Cairo conducted a total of 16 focus group discussions and 20 indepth interviews in four cities in Egypt (Giza, Alexandria, Minya and Dakahliya) to investigate perceptions and positions on aspects of masculinity and identity. ${ }^{3}$ The research was commissioned for an international study on masculinity in four Arab countries (Morocco, Egypt, Lebanon and Palestine) and involved both quantitative and qualitative research (not ethnographic work). The SRC was charged with the qualitative research which meant designing this component for the whole research effort and implementing it in Egypt. Participants for the FGDs were recruited via local community NGO's. A write up of the project objectives and details was shared with 4 community based NGOs and they were asked to call for volunteers to participate in the group discussions which took place in the NGO headquarters in mostly lower income neighbourhoods in the suburbs and peri-urban areas of each location. An informed consent form approved by the AUC IRB committee was circulated to ensure that each participant knew that participation is voluntary and that the discussions were for research purposes only. Contact information for the SRC were shared in case any participant wanted recourse for action taken concerning the discussion itself or post discussion concerns

Approximately 160 individuals participated in the 16 group discussions. They are equally distributed along gender and age categories. The purpose of these discussions was to better interpret findings from survey of the practices and choices of almost 2000 men and women concerning gender in general and 
masculinity in particular that had been fielded in the same areas from which group discussions participants lived. Some of the participants had also taken part in the survey.

The group discussions were designed to probe into four topics that had been uncovered by the survey. The topics included the meaning of being a man in Egypt in the present as compared to times gone by, male physical and mental health and well being, ${ }^{4}$ affective relations and the perceived consequences of recent legal provisions and political practices that favour women on men. The analysis of these conversations is instructive to this discussion as it provides meat for thought on how women and men reflect on gender norms and experiences in ways which are not fixed in a geography and where gender is discussed in terms of the experiences of both men and women.

Qualitative research has limitations. It is neither rigorous enough to satisfy statistical standards for representation nor deep and engaged enough to comply with ethnographic standards of 'truth' and meaning (Sholkamy 2006). But these artificial settings for research do enable 'natives' or respondents to represent themselves in accordance to their own self images and desires. The artificiality of the research encounter precludes any possibility of fixing people in a cultural setting but it also means that the broader contexts of class, nation, observer and observed collide and enable a narrative that is an idealized and perhaps exaggerated version of self and other.

"El-regoolah" is the term that discussants used to expresses the moral construction of masculinity. There were three renditions of this term in the discussions. Each rendition is highly correlated with the age and gender of the discussants ${ }^{5}$.

Younger men tended to define el-regoolah as the ability to impose one's presences, identity or opinion on others. "His word must be followed and he is the one who is right" is one way a participant described a person who is a Man! Young women also shared in this view. Older respondents described el-regoolah as exalted morals, fortitude and forgiveness. They however lamented (as is typical everywhere in the world when the old evaluate the young and express nostalgia for the past) the lack of respect and the crass behaviour of the young men who have lost all sense of propriety and respect for others. They blame this sorry state of affairs on family upbringing, media and the absence of the state! A third interpretation of el-regoolah is that it is the traits of courage, responsibility and fortitude. Women participants expressed this idealized notion of maleness.

The roles and responsibilities of men were on the whole described as being supportive of family and of women. Men should be protective, helpful, 
respectful of women and able to provide for their families as well as provide them with moral guidance. Most importantly and so as to be able to fulfil these responsibilities, men need a good sound and attentive socialization and upbringing and most importantly, a job. Families should take care of young boys and nurture, protect and guide them so that they can become good men who find employment and are able to, themselves, then support families of their own. However, it is not only the family that creates a man. Participants fully recognized the role played by schools, friends, relatives and the media. They all agreed that the meaning of maleness is not static and that people change depending on their age, experiences and milieus.

The effect of women on shaping maleness is profound according to most participants. Some participants believe that when women behave in a brazen way or dress offensively, this 'forces' men to look at them which in turn frustrates the man and causes problems. ${ }^{6}$ Some think/believe that when women are in higher professional positions than men at work, this is embarrassing to the men in junior positions and may also cause problems.

Some participants lamented women's work as a cause of imbalance inside the family. When women work and earn, they undermine their husband's natural role as responsible provider. This is the role of men as stipulated in religious texts and moral practices. Therefor women workers should avoid asserting their contributions as providers for the family since it is now accepted that a family cannot survive with one income and that men and women share the burden of providing. Women's work is not a problem as long as women do not let their role as provider seep into the home environment. But many other participants felt that women do not affect men's behaviour and that men and women are equal and should only be differentiated by their abilities, morals and knowledge. These respondents said that times have changed and families need both couple to provide and to share responsibilities.

Whereas some participants completely reject the ideal of men sharing or participating in housework, other see no problem with men taking on household chores saying that the pressures on women are too much for any one person to bear alone. Some said that geographical location matters and that gender roles are dictated by where one lives and how conservative the community is. The main disadvantages or burdens of being a man have to do with the male provider role. The difficulty of supporting a family and of finding the resources necessary to get married weigh heavily on men in society according to the participants.

The discussions on health point to a widely accepted situation of crisis. The status of men's health in Egypt was described as serious and critical. As one participant explained: "Most men now to be able to work need Birsham (pills). These (the pills) are basic at the beginning of the day. As soon as you start a 
day's work if you have no pill you do not work. Today some people are really this dependent".

Participants blame economic conditions which burden and pressure men psychologically leading them to smoke and take drugs therefore leading to physical morbidities such as respiratory diseases, hypertension, and gruelling lifestyles. Later on in life they develop other diseases such as diabetes and obesity. Men's physical health is also affected by pollution (air and water). But work and social pressures are the main cause of diseases. In many cases, men have to take more than one job to be able to provide for their families and dependents, so they get little sleep and in some cases either not enough food (leading to anaemia), or too much fast food leading to obesity.

The other main factors of influence on men's health are narcotics and stimulants. Participants said that the use of these drugs is ubiquitous and that they are affordable and easy to find, which leads to high rates of utilization and dependence. When asked to describe the ideal body type or physical features of men all participants linked physical appearance and physique to age and socioeconomic status. Poor men cannot afford the luxury of an athletic or wellfed body. In terms of age, the young should strive towards having a strong muscular body but for the old, a good body is one that is free of diseases and disabilities.

Ability (qudrah) means fulfilling a man's' economic role of bread-winner, parental role of moral guide for children and sexual role as husband. The inability to fulfil the latter is often due to economic pressures. Inability or $a g z$ in Arabic meant more than impotence. It also means the inability to fulfil a male's economic duties. Participants identified a lack of state support for men's health and lamented the deficit in male focused curative care and identified drug testing and awareness campaigns as an urgent need as drugs and stimulants have destroyed male lives and livelihoods. Many were also troubled by pornography and considered it a disease that has created male sexual frustration. Some men said that they feared the pervasiveness of online pornography and its impact on male morals and even on female modesty. On the whole the subject of sexual insecurity resounded throughout considerations of male health and ability.

The new laws that have been passed and which instil some legal equality in society were familiar to most. All participants were aware of laws to reorganize personal status rights, to criminalize sexual harassment and to give women rights to mobility and to unilateral divorce or (khol'). Some participants felt that these changes had undermined men. As one put it: 
Of course these laws have had negative effects. Before women were blind (oblivious) and her husband was a Si Sayed (a fictional figure from the Novels of Naguib Mahfouz who was an autocratic patriarch) and she had to obey his bidding. Now her eyes have opened to every big and small issue and she can threaten her husband with Khol.

Group discussion participants differed in their opinions but not along gender lines. For some it is a zero sum game with women's work and public roles taking away from male authority and status. For others gender equality and complementarity are a good and natural norm. There were women who said that these legal changes had some bad outcomes with one saying that her sister's brother said to her during a fight "let the state protect you" as he walked out! Some men were glad that these rights to unilateral divorce and to mobility had enabled their own kin (sisters, cousins) to get out of a bad relationship.

Despite the many laws and institutional arrangements that have favoured women in the past decade, most participants see women's work as the most significant factor in instilling gender equality. "Having an independent income has led to women thinking that they are equal to men and has even made them neglect their duties such as caring for children", said one respondent. Some male participants claimed that there was a 'crisis in masculinity' due to women's empowerment. Women having economic/earning ability stand up to men and undermine male prerogatives. Some fear the misuse of these new laws, in particular the sexual harassment law which can be invoked by women unjustly to blackmail or punish men. When asked about their own personal experiences or that of their kin or network with the ramifications of these laws and decrees, most said that it $\mathrm{s}$ the personal status changes that have had most impact.

\section{Convergences and Divergences}

Most observers of urban and peri-urban Egypt will recognize the familiar refrain echoed in these conversations. Anthropologists have worked on men and masculinity as identity (Ghannam 2002, 2013), as partners in intimate relationships (Hoodfar 1997), as an issue of crisis (Ammar 2011) and as victims of sexualized cultural hegemonies (Massad 2007). There are themes of anxiety, connectedness, conflicts/contradictions, and nostalgia that are easily discernable in the transcripts and which have appeared in the work of many scholars. Men are anxious either for themselves or for their loved ones or peers. Deteriorating health, escalating drug dependency, diminished status and heightened economic needs are the main features of this anxious world. Women are anxious about men and their abilities and capabilities. A critic of the used methodology may (rightly) say that the expressed fears and positions may not be real or enacted. 
Perhaps men would feel differently if questioned in the company of relatives? Perhaps they say one thing and do another. Perhaps women are less tolerant or more submissive then they claim. But ethnographies may not be able to capture truth in any better way. The transcripts show a version of cultural knowledge that is not informed by a fixed reality but that is conversant with broader contexts.

Anthropologists of the Middle East have been credited with describing the private worlds of women in Islamic worlds (Abu-Lughod 1998). Yet perhaps this theme of separation has been exaggerated as is evident from testimonies that express connectedness. Maybe men and women inhabit different public spaces but they jointly negotiate daily life. They have intertwined and complex relations that effect and transform one another in subtle and pronounced ways. Hoodfar has shown the inter-relatedness of men and women in her work in urban Cairo (Hoodfar 1997). Ghannam has described the overlapping circles and circuits whereby masculinity is negotiated and appropriated (or approximated) also in Cairo (2013).

Men may have no problem with laws that mandate rights for women but will be unhappy when these laws detract from their ability to impose their will or when they effect the outcomes of a conflict by for example forcing a man to grant a divorce. But they will celebrate these same laws when they favour their sister or daughter. People may also be conflicted when judging others but exempting themselves. Thus women's work is a modern bane but all women interviewed worked and some men who disdained the work of women had wives and mothers who worked.

Ultimately the past was where many took refuge and is the space where relationships worked. Some young women saw progress on issues relating to women's formal rights as a great recent gain but even they were nostalgic about other aspects of the past such as stable families, loving mothers and righteous protective fathers. In the past women and men were able to resolve their own problems, live on a pittance, find work and have children without worrying about economic burdens. While the past is described by some in terms made popular by films and by television where relationships and daily lives are dramatized beyond the realm of the possible, others remember a bitter sweet time of fewer conveniences and fewer worries.

Men and women share common worries concerning economic insecurity. Fear of economic need seems to be driving women to work and men to drugs. Economic expectations have the power to conquer loving relationships. Material conditions are blamed for lost morality and lost respect. These issues are present in most discussions as women and men filter gender norms through economic 
experiences and expectations and speak of economic hardship, anxieties of impoverishment and unemployment and of small incomes and big bills.

This reading of a small number of group discussions will worry ethnographers and critical social researchers who may be dismissive of social research that is tethered to wobbly epistemological moorings such as group discussions (Sholkamy 2006). The veracity and value of social facts after all are contingent on the depth, breadth and length of social engagements. Ethnography, the prolonged engagement in natural settings relies on native perceptions, knowledge and theories for its interpretive path. ${ }^{7}$ Critical scholars immerse themselves in action guided by the experiences of engaged first hand agents so as to relay positional and positioned meaning and promote politically informed understanding. These focus groups do none of that. They at best produce steadfast aphorisms about gender and relationships well known to many.

Despite lack of depth and immersion these discussions reveal complex, unstable, and nuanced views on gender that defy unitary or essentialist interpretations and theories. The transcripts show states of hesitation, of possibility, of uncertainty, of fluidity and fixity that may escape the tools of the ethnographer keen to show a core of cultural knowledge and certainty. These conversations express aspects of a class and public culture 'buzz'. They repeat that which is accepted as a public statement of opinion. They may lack depth but they have breadth. The discussions express locally sanctioned recognition of what we could call 'the state of gender'. This middle strata of research does not provide evidence per se but it does avail directions for interpretation and a space where the researched agent is free to interact and reflect beyond the boundaries of locality.

\section{Finding Real People}

Critics of gender activism and of state led feminism in Egypt have belittled the work of state and civil society questioning the relevance of this work to the lives of 'real' women and (Abu-Lughod 2010, Al-Ali 2000, Jad 2008). They have identified the distance of elites who lead formal gender justice agendas from the women who are most in need of justice. Jad pointed to the demobilization of grass-root feminist movements by globally connected gender organizations thus blaming gender rights agents and their agenda for undermining grass-root women's collectives informed by a national liberation cause in Palestine. Mahmood has also critiqued the relevance of the modernist agenda and its dislocation from morally guided (and by necessity more authentic) framings of rights and of justice (Mahmood 2005). Abu-Lughod's invitation to engage with the social life of gender rights in an ethnographic context implies that there is a chasm between the experiences of gender justice 
(or as she describes it "Muslim women's right") in the village and the intent of gender rights agendas in policy circles. ${ }^{8}$ She suggests an understanding of the mediation of gender rights through different social networks and technical instruments (Abu-Lughod 2010, 3). These calls for inversion of the power structures that govern gender rights and which privilege globalized seemingly ahistorical models of equality and empowerment over the political, historical and grounded experiences and interests of people (ordinary or not) are important. But they also invite a methodological concern for the ways in which ethnography is used as evidence or as a moral and political searchlight that exposes empirical reality. Are these calls 'fixing' the local as a particular local and do they under theorize the connectivity of various circles of power, influence and change? ${ }^{9}$

Al-Azmeh (2009) in the opening quote to this article, is questioning the possibility of cross-cultural conversations because they take for granted that the conversant parties are fixed and final. Spivak, in an extension of her article 'Can the Subaltern Speak?' questions the way in which native informants are imagined as auto-artifacts (without conscious self-reflection) and while identified and prized, they continue to be without a voice. They speak a dominant language so as to create evidence, and thus "the figure of the woman disappears not onto a pristine nothingness but into a violent shuttling that is the displaced figuration of the third world woman caught between tradition and modernization, culturalism and development (Bhattacharjee 2001, 1195-7).

An epistemic shift from particularism to wider connected circuits of experience and of exchanges of ideas would enable a better understanding of conglomerations of agency and identity. Broadening the scope of gender to include relationships not just individuals would help analysts understand the complex ways in which women and men change one another. Adding depth to place and broadening the scope of the local would help researchers fully understand and engage with the contexts that shape social experiences. This shift would problematize the words "ordinary" and "real". It would bely the idea of native and of fixed authenticity.

\section{The Many Faces of Agency}

Personal Reflections: Early in the morning while looking out of a window from the apartment that my family built in a small hamlet in Upper Egypt, I watch the scores of local women dressed in conservative Egyptian fashion walking out to the main road to catch a ride to the nearby towns where they work as school teachers, health workers, administrators and state employees. Many are cousins and relatives. Most are wives and mothers who on their early afternoon return home will be resuming their roles as home-makers, cultivators, 
wives and mothers. They will milk the cows, bake bread in mud ovens and support the family economic livelihoods through food processing and multiple home based activities. They are middle class at work and peasants at home. They desire to educate their children and marry them off to suitable kin at the earliest opportunity. They may be trenchant in how they wield administrative power but deferent at home to husbands and fathers. I wonder if they have one self-image or two or many.

Young (in Strathern 1981) has critiqued the way of which stereotypes are sustained in activist and political narratives. The imaginary that creates standardized relations or assumed structures yields a totalizing gaze that confirms binaries by making evaluative judgments of formal structures on the basis of ethnographic evidence. It is banal to note that people are complex and multi-faceted. Yet ethnography can often serve to fix identity by privileging one of its manifestations and undermining others. A universal meaning of womanhood for example is "manufactured" when variant, multiple and grounded symbolic constructions of gender are occluded or interpreted away by an ideologically driven anthropology (Strathern 1981).

Perhaps there are crossroads at which a person through choices and actions negates a facet of their inner self and projects another. But these choices may not be consistent. A progressive academic working at a privileged institution that is accessible to students only through fierce competition or for astronomical sums of tuition is entitled to both her position and her principles. A native of an Assiut hamlet also has the right to similar contradictions. She may work but hope that her daughter does not have to. The task of finding the native to negate elites is confounded by the complexity and connections of life. Recognizing the way in which women and men are performing variations on the theme of gender enables a reading of society that is clear of false binaries and premises of dislocation and social distance. This reading can address the tensions of invoking universalistic rhetoric (like gender justice) through seeking radical particularity (Calhoun 1995, xxiv-xxv).

Abu-Lughod speaks of multiple registers by which to trace the social life of rights talk in local settings. She draws attention to national media platforms that mediate a rights discourse through drama, a "developmentalist discourse' on education that projects principles of economic opportunity as grounds for a principled equality, a religious moral framework that arbitrates gender tensions and dictates models of behaviour and demeanour and a traditionalist or local community that proscribes how women and men behave and transact differences and entitlements (Abu-Lughod 2010, 29-31). But in tracing the enactments and applications of concepts of rights through distinct networks of socialization, 
communication, inspiration and social organization we also need to permit the fluidity with which these structures articulate with practices and perceptions. We need to be wary of the projects of fixing people in moulds circumscribed by research itself. These boundaries write out men from stories of gender, or project them as supportive or abusive others. They may dissociate gender as social role from the underlying sexual intimacies that shape or inform these roles. They may also create a choice between "ordinary" and "other", and perhaps even unintentionally enable or reify circumscribed spaces of localism.

Taking the social practice of rights as an object of ethnographic enquiry (Goodale 2006 quoted in Abu-Lughod 2010, 32) should not only take us to the women cast in roles of dire oppression then observed and interviewed so as to restore or uncover their agency, but also require that we avoid circumscribing their social, intimate and political worlds in ethnographic straightjackets. We could also then better trace the articulations of multiple registers and trace the paths of influences and change beyond the ethnographic present and the boundaries of places. By so doing we would no longer carve out separate circuits of influence that separate women's worlds from policy and development regimes. These are historically constructed worlds that are mutually constitutive and are similarly subject to structural conditions. The story of gender and women's rights as a historical narrative is pertinent and relevant to gender rights as social facts. The formal and activist narratives of rights do not author change but they perhaps create an environment in which change happens. They may be relevant to a middle arena where change becomes possible and without which change would not happen. If analysts focus on outcomes and ignore processes they will fail to see this liminal space where ideas and possibilities percolate.

\section{Women in National Narratives}

One of the victories of the transformation of Egypt that began on the $25^{\text {th }}$ of January in 2011 has been a formal acknowledgement and enactments of gender rights. ${ }^{10}$ There are record numbers of cabinet ministers (8) and deputy ministers (5), senior regulators and administrators, parliamentarians (18\% of parliament). A number of laws and decrees that had been demands of the feminist movement have also been easily enacted thanks to the strong pro-women political will that prevails. Laws that criminalize sexual harassment and denial of inheritance have been passed and the rights gained previously to mobility, unilateral divorce and child protection have been confirmed. Moreover, there is a strong appetite to tackle old burdens such as child marriages, rights to inheritance and women's access to work and property. Most importantly the Egyptian constitution of 2014 is fully committed to gender equality and to the rights of women. 
In the decades preceding 2011, the calls for gender rights and justice had been fully adopted by the state but the popular acceptance of these calls was lukewarm. In 2000 a National Council for women was created by presidential fiat so as to hold the state accountable to its obligations of gender equality as mandated by international agreements and conventions. The governmental/regime appropriation of gender agendas was not without outcomes. The right to mobility, to unilateral divorce (Khol'), to a longer custody of children in cases of divorce and to educational guardianship of children were some of the achievements of this agenda. From a developmental point of view the council was a success as it had managed to shepherd a number of internationally recommended policy initiatives that address structural inequalities but from a political one it became the focus of scorn and hatred as the phenomenon of state sponsored feminism that the council embodied became an ever more apparent thorn in the side of Egypt. Figuratively and physically, the council was burnt down along with the ruling party headquarters in which it had its main offices by the protestors of January 2011 as its premises were torched on $28^{\text {th }}$ of January and as the principles of elitism and exclusion upon which it was built were reviled. The revolution rejected the official face of gender politics but what of the cause itself?

The dismal 2\% representation of women in the parliament dissolved by SCAF after the constitutional court ruling of the $17^{\text {th }}$ of June 2011 , and the threats to established rights to divorce and custody made by some parliamentarians all added up to alarm and a sudden realization that revolution and its anticipated freedoms would not necessarily free women!

A women's political movement re-emerged to establish the centrality of gender to social justice in Egypt. Networks of young women with no qualms about demanding equality and no tolerance for the shy and less abrasive ways of the past that settled for equity became active and vocal Political parties born after the 2011 revolution accepted and respected their women's committees. The protests against the constitutional amendments of November 2012 were astounding for their recreation of gender balance first witnessed in Tahrir Square in January 2011. Women networks raised millions to fund the no vote and to organize logistical support for demonstrators as well as to act as observers during the referendum itself. Even the yes vote crowd brought out its women members to show gender blind support for the president and for the constitution!

The participation of women in the 2013 demonstrations was as significant as it was in January 2011. Their participation and support has cemented the perception that women are symbolically and statistically a pro regime group whose voices have been heard. Needless to say there are women who were 
supportive of the Muslim Brotherhoods and who have been victims of a clampdown.

The mobilization of women in Egypt has not been limited to formal circles. Mahmood has described the mosque movement in Cairo as a venue for collective voice and action that enabled women to construct moral worlds in which they could shape their agency and the society in which they lived (Mahmood 2005). Religion was more successful in moving women towards collective action and political participation as well as community service in ways that no other force or idea could inspire. However? There were women active in the labour movement, in the human rights world and on the internet who neither were interested in the formal politics of gender as espoused by the national council for women, nor were they enchanted by the moral messages of mosque or church communities. These groups of new feminists were active in countering forms of harassment and defending the personal rights of young women (Magdy 2017). The recent past has witnessed a broader engagement with women's 'rights' and presence in public political arena. Gender work has had more relevance than perceived or predicted. The manifestation of diverse groups of women and men, each with different renditions of pathways to gender equality, illustrates that gender activism beyond religion exists.

There is a disconnect but it is not between ordinary and extraordinary women or between elites and the masses. The lingering sense of irrelevance of gender rights to the lives of 'real' women is due to the inability of gender elites, whether religious, formal, activist or progressive, to address the sexual and intimate worlds of women and men. If there is a disconnect between formal narrative and lived worlds it may be well described as the inadequacy of gender rights work in addressing sexual injustices and in understanding how these intimate connected lives create burdens of inequality and injustice. Islamic activism did restore the focus of sexuality to gender but in ways that idealized these intimate worlds and imposed highly structured and disciplined gender roles on the world of sexual relationships (Mahmood 2005). But the distance between gender as a set of formal rights and gender as a sexual identity has had limited purchase in recent gender research. The work of rights is doing well in the world of rights. But women and men may not see the connection between the rights of gender equality and the burdens of intimate worlds.

\section{Sex and Gender}

Foucault's conception of sexuality, not as an innate or 'natural' aspect of the body but rather the effect of historically specific power relations, provides a useful analytical framework for explaining how women's experience is 
diminished and controlled within certain culturally shaped notions of female sexuality. The body is a cultural, rather than a 'natural' entity. Unlike Freud's emphasis on repression, Foucault's contention has been that specific discursive practices in which power is always implicated in the structure of desire and sexuality inform experiences of body, of relationships and of intimacy (Foucault 1984). These practices filter the discourse of gender into everyday life

Scholars working in Egypt and on the Arab world have questioned the conceptual understanding of sexuality and its articulations with gender ${ }^{11}$ and argued for a contextual, political, critical and non-essentialist approach to the study of power relations as practiced in personal/intimate spaces and relationships. Mikdashi (2012) has authored a similar argument on how not to study gender pointing to the uselessness of labels and taken for granted notions of gender injustices and their causations. She warns against the neglect of sexuality in understanding gender and of the analysis of evidence to the neglect of the processes that led to the state of affairs that we call evidence of injustice. Like Massad (2007), she points to the mistaken assumptions of Orientalist approaches, which ignore the role of modernity itself in the creation and consolidation of inequalities. Both Massad and Mikdashi are inviting a sensitivity of sexuality and of enactments of sexual roles to a gender analysis. This invitation can be read as a critiques of formal, particularly state led gender agenda but is also a reminder that the recognition of sexuality as a culturally constructed discursive practice that defines gender roles in multiple and conflicting ways may serve to challenge the facile interpretations of 'evidence' and necessitate an acceptance of fluidity and uncertainty. This recognition will also enable us to understand the limitations of gender work not doubt the intents of its proponents.

The reflections and conversations considered in this text illustrate the standpoint theory of Dorothy Smith and other feminists in which the "bifurcated consciousness that recognizes the split between impersonal discourse of power and the personal realm of concrete relations" operates. Smith described daily life as a puzzle if viewed from an omniscient point of view that ignores power or from a particularist vantage whereby the social relations external to peoples experiences are unaccounted for or ignored. Unmasking the false impersonality of systems like the state and the economy which appear as though they were actor-less is vital but so is understanding the ways in which these systems appear and act in daily life (Smith 1987, Calhoun 1995, 187).

People may like or dislike the narrative of gender rights. They may resort to or ignore the support afforded by more equitable laws. They may cling to notions of tradition or prize the clarity of moral strictures on what it means to be male or female. These are their personal and incontestable rights not just evidence of a 
political stance. The conversations cited in the opening section point to the need for discerning the ways in which social, political and cultural currents shape notions of sexuality, of intimate space, of the body and of family. The ecosystem created by gender and development work provides a context in which these important aspects of lives are constructed and transacted.

The manner in which political and research work conflates gender and sexuality can lead to a schism in understanding whereby we imagine that relationships can be legislated or circumscribed through formal interventions and laws. It is equally misguided to think that these gender agenda, whether global or domestic, are not relevant to social life. The inadequacies of the gender agenda lie not in its origin or networks but in its inability to address the sexual aspects of gender and the intimate relationships that inform the day to day lives of women and men. Ethnographic work that engages with the desires, pressures, resources and identities that shape relationships, can potentially transcend the limitations of nativism. Grounded, connected and historically informed ethnography and empirical social research can transcend the limitations of gender rights but not because it is focused on the ordinary woman in her cultural space but because it can engage with the intimacies that undergird experiences of gender.

I have argued that when tracing the social life of gender rights, we need to account for the social lives of other contending influences on gender. And we need to free the agents of the local from fixity and localism to enable an understanding of the broad and fluid circuits of daily, and political lives. In the middle domain between village and state elites is a world of interpretation in which gender is shaped by intimacy. Elites and ethnographers may not be able to capture or analyse this world but they may be able to see their limitations in terms of this silent space.

The problem with rights work is not that it is distant from real people but rather that it is disengaged from sexuality. The conversations with men and women quoted in this article illustrate the degree to which physical ability, relationships, anxiety and health are important to individual men and women. These concerns reflect the importance of intimate life and relationships. Rights work has enabled changes in state and public perceptions of gender rights but it has had limited effect on the transactions of gender and the sexual and intimate lives of people in Egypt. These limitations are similar to the shortcomings of ethnographies where intimacy is ignored. The importance of informed ethnography is illustrated in the work of Abu-Lughod herself who began investigating the intimate world of Bedouin women and their expressions of love and longing (Abu-Lughod 1986). The basis of a critique of gender work needs 
to lie not in the quest for the authentic native but in the appreciation of the inner worlds of gendered subjectivities.

The world of women has changed in Egypt and many of the items on the check-lists of formal gender justice have been ticked. This has been the intent of gender work. The more difficult domain of intimate lives and gendered relationships however has eluded so far elites and researchers.

\section{Endnotes}

${ }^{1}$ For example, in Egypt and since the political upheavals that began in 2011, feminist and rights groups have been doubted as lackeys (Abdelrahman 2004), denigrated by the popular media as the triggers that began the travails of 2011, and some along with other human rights activists have been prosecuted for their funding practices.

2 Also see by Abu-Lughod, Lila. 2002. Do Muslim Women Really Need Saving? Anthropological Reflections on Cultural Relativism and Its Others. American Anthropologist 104, no. 3: 783-90 and Abu-Lughod, Lila, Fida J. Adely, and Frances S. Hasso. 2009. Overview: Engaging the Arab Human Development Report 2005 on Women. International Journal of Middle East Studies 42, no. 1: 59-60.

${ }^{3}$ The author is principle investigator of this project which was undertaken as part of a broader research initiative led by Promundo USA, funded by UNWomen and in collaboration with Zanaty and associates. The SRC team included Dr. Faten Ali, Dr. Ramadan Hamed, Mr. Mohamed Hassan and a small number of assistants and enumerators.

${ }^{4}$ Including dependency on tobacco and stimulants, sleep patterns, body ideals, ability and disability, weight, vulnerability and risks, diseases, health seeking behaviour and self-care.

${ }^{5}$ An informed consent form approved by the AUC IRB committee was circulated to ensure that each participant knew that participation is voluntary and that the discussions were for research purposes only. Contact information for the SRC was shared in case any participant wanted recourse for action taken concerning the discussion itself or post discussion concerns.

${ }^{6}$ Mashakel is a favourite word for many. It means problems but does not indicate a moral position from these problems.

${ }^{7}$ Among the disciplines of cultural production of alterity, anthropology is perhaps the most important rubric under which the native other was imported to and exported from social science theory (Calhoun 1995, 125).

${ }^{8}$ The concept of 'Muslim women's rights' is problematic as it seems to imply that there is something called The Muslim Woman. Women's rights in Islam or according to Islamic interpretations, scholars, jurists or legal systems would be a term that is less confounding. 
${ }^{9}$ For a discussion of the tensions of globalized and localized narratives of gender and feminism see Mohanty, ChandraTalpade. 2003. Under Western Eyes" Revisited: Feminist Solidarity through Anticapitalist Struggles. Signs 28, no. 2 (Winter): 499-535. The University of Chicago Press. Accessed: 12-07-2018 11:25 UTC; Mohanty, Chandra Talpade. 1986. "Under Western Eyes: Feminist Scholarship and Colonial Discourses." Boundary 2 12, no. 3: 333-58; and Narayan, Uma. 1997. Dislocating Cultures: Identities, Traditions, and Third-World Feminism. New York: Routledge.

${ }^{10}$ For an account of political rights for women in Egypt see Sika, Nadine and Yasmin Khodary. 2012. One Step Forward, Two Steps Back? Egyptian Women within the Confines of Authoritarianism. Journal of International Women's Studies 13, no. 5: 91100.

${ }^{11}$ For a discussion of the moral and political constructions of sexuality see: Stoler, Anne. 1995. Race and the Education of Desire: Foucault's History of Sexuality and the Education of Desire. Duke University Press.

\section{Works Cited}

Abdelrahman, Maha. 2004. Civil Society Exposed. Cairo: The American University in Cairo Press.

Abu-Lughod, Lila. 1998. Remaking Women: Feminism and Modernity in the Middle East. New York: State University of New York Press.

Abu-Lughod, Lila. 2002. Do Muslim Women Really Need Saving? Anthropological Reflections on Cultural Relativism and Its Others. American Anthropologist 104, no. 3: 783-90.

Abu-Lughod, Lila, Fida J. Adely, and Frances S. Hasso. 2009. Overview: Engaging the Arab Human Development Report 2005 on Women. International Journal of Middle East Studies 42, no. 1: 59-60.

Abu-Lughod, Lila. 2010. The Active Social Life of "Muslim Women's Rights": A Plea for Ethnography, Not Polemic with Cases from Egypt and Palestine. Journal of Middle East Women's Studies 6, no. 1 (Winter): 1-45.

Abu-Lughod, Lila and Rabab El-Mahdi. 2011. Beyond the "Woman Question" in the Egyptian Revolution. Feminist Studies 37, no. 3 (Fall): 683-691.

Al-Azmeh, Aziz. 2009. Islams and Modernities $3^{\text {rd }}$ edition. Verso.

Ammar, Paul. 2011. Middle East Masculinity Studies: Discourses of "Men in Crisis," Industries of Gender in Revolution. Journal of Middle East Women's Studies, 7, no. 3:36-70.

Bhattacharjee, Sukalpa. 2001. Towards a Theory of Native Informant. Economic and Political Weekly 36, no. 14/15 (April 14-20): 1194-1198.

Calhoun, Craig. 1995. Critical Social Theory. Oxford: Blackwell Publishing. 
Foucault, Michel. 1984. The History of Sexuality. Gallimard.

Ghannam, Farhah. 2002. Remaking the Modern: Space, Relocation, and the Politics of Identity in a Global Cairo. Berkeley: The University of California Press.

Ghannam, Farhah. 2013. Live and Die Like a Man: Gender Dynamics in Urban Egypt. Stanford: Stanford University Press.

Goodale, Mark. 2006. Introduction to "Anthropology and Human Rights in a New Key". American Anthropologist 108 (1): 1-8.

Hatem, Mervat. 2011. "Gender and Revolution in Egypt", Middle East Report 261 (Winter).

Hoodfar, Homa. 1997. Between Marriage and the Market: Intimate Politics and Survival in Cairo. University of California Press.

Khater, Akram \& Cynthia Nelson. 1988. Al-Harakah Al-Nissa'Iyah: The Women's Movement and Political Participation in Modern Egypt. Women's Studies International Forum 11, no. 5 (December): 465-483.

Jad, Islah. 2008. Demobilization of the Palestinian Women's Movement in Palestine: From Empowered Active Militants to Powerless and Stateless citizens. MIT E Journal of Middle East Studies 8 (Spring): 94-111.

Magdy, Rana. 2017. Egyptian Feminist Movement: A Brief History. OpenDemocracy. https://www.opendemocracy.net/en/north-africa-westasia/egyptian-feminist-movement-brief-history. Retrieved 15 July 2018.

Mahmood, Saba. 2005. Politics of Piety: The Islamic Revival and the Feminist Subject. Princeton: Princeton University Press.

Massad, Joseph. 2007. Desiring Arabs. Chicago: The University of Chicago Press.

Mikdashi, Maya. 2012. "How not to Study Gender in the Middle East". Jadaliyya. 21 March. http://www.jadaliyya.com/pages/index/4775/how-notto-study-gender-in-the-middle-east.

Mohanty, Chandra Talpade. 1986. "Under Western Eyes: Feminist Scholarship and Colonial Discourses." Boundary 2 12, no. 3: 333-58.

-----. 2003. "'Under Western Eyes' Revisited: Feminist Solidarity through Anticapitalist Struggles". Signs 28, no. 2 (Winter): 499-535.

Mostafa, Dalia, ed. 2018. Women, Culture and the January 2011 Egyptian Revolution. Routledge.

Narayan, Uma. 1997. Dislocating Cultures: Identities, Traditions, and ThirdWorld Feminism. New York: Routledge.

Sholkamy, Hania. 2006. The Frustrations and Future of Teaching Qualitative Methods. The Anthropology of the Middle East 1, no. 2: 201-34. 
Sika, Nadine and Yasmin Khodary. 2012. "One Step Forward, Two Steps Back? Egyptian Women within the Confines of Authoritarianism". Journal of International Women's Studies 13, no. 5: 91-100.

Smith, Dorothy. 1987. The Everyday World as Problematic: A Feminist Sociology. North Eastern University Press.

Smith, Dorothy. 1990. "Women's Experiences as a Radical Critique of Sociology". In Feminism and Methodology, edited by S. Harding, 84-96. Bloomington Indiana: University of Indiana Press, 84-96.

Stoler, Anne. 1995. Race and the Education of Desire: Foucault's History of Sexuality and the Education of Desire. Duke University Press.

Strathern, Marilyn. 1981. "Culture in a Netbag: The Manufacture of a Subdiscipline in Anthropology." Man. New Series 16, no. 4 (December): 665688 . 